\title{
Aktivitas Enzim Peroksidase dan Kadar Klorofil pada Daun Angsana (Pterocarpus indicus) sebagai Peneduh Jalan yang terpapar Timbal
}

\author{
Anjar Astuti Ferdhiani, Sri Lestari, Elly Proklamasiningsih \\ Fakultas Biologi Universitas Jenderal Soedirman, Purwokerto \\ e-mail: anjarferdhiani@gmail.com
}

\begin{abstract}
One of emissions in the air that's harmful to human health is lead $(\mathrm{Pb})$. The negative effects caused by lead and then required solutions for reducing the metal, its called phytoremediation. The Plant which acts as an agent of phytoremediation is Angsana (Pterocarpus indicus Willd.). Research to find out the lead content in Angsana's leaf at four locations, knowing the influence of exposure to lead against the activity of an enzyme peroxydases and chlorophyll content in the Angsana's leaf. The location for collection of samples conducted in four location at Purwokerto (1) H.R Bunyamin, (2) Ovis Isdiman, (3) Gerilya, and (4) Dr. Soeharso. A method of the sample used purposive sampling. Sample were analysed using wet digestion method, then were analysed using Atomic Absorbance Spectrofotometer (AAS). The activity of peroxydases and levels of chlorophyll were analysed using spectrophotometer Uv Vis. Result showed that the lead content in Angsana's leaf is $0,1-0,25 \mathrm{mg} / \mathrm{L}$, the activity of peroxidases is $600-$ $1250 \mathrm{unit} / \mathrm{g}$ and chlorophyll content is $9,0-21,0 \mathrm{mg} / \mathrm{L}$. The conclusion was no relations about chlorophyll content with levels of lead content and the relations about activity of enzymes peroxydases and lead content is low . Content of lead on Angsana's leaf of research has been done do not reach $1000 \mathrm{mg} / \mathrm{L}$.
\end{abstract}

Key words: Peroxydase enzymes, Pterocarpus indicus, Chlorophyll, Lead (Pb)

\begin{abstract}
Abstrak
Satu dari emisi di udara yang berbahaya bagi kesehatan adalah timbal $(\mathrm{Pb})$. Banyak dampak negatif yang disebabkan oleh timbal, diperlukan solusi untuk menurunkan kadar logam diudara yaitu dengan fitoremediasi. Salah satu agen fitoremediasi adalah tanaman Angsana (Pterocarpus indicus Willd.). Penelitian ini bertujuan untuk mengetahui kadar logam pada daun Angsana di empat lokasi, mengetahui pengaruh timbal pada aktivitas enzim peroksidase dan kadar klorofil daun Angsana. Lokasi pengambilan sampe yaitu di jalan (1) H.R Bunyamin, (2) Ovis Isdiman, (3) Gerilya, and (4) Dr. Soeharso. Metode pengambilan sampel menggunakan purposive sampling. Sampel dianalisis menggunakan metode Atomic Absorbance Spectrofotometer (AAS). Akitivitas enzim peroksidase dan kadar klorofil dianalisis menggunakan spektrofotometer Uv Vis. Hasil penelitian menunjukkan kadar timbal pada daun Angsana sebesar 0,1 - 0, $25 \mathrm{mg} / \mathrm{L}$, aktivitas enzim peroksidase 600- 1250 unit/g dan kadar klorofil 9,0$21,0 \mathrm{mg} / \mathrm{L}$. Kesimpulan dari penelitian tersebut tidak ditemukan hubungan korelasi antara kadar klorofil dan kadar timbal pada daun Angsana dan hubungan antara aktivitas enzim peroksidase dengan kadar timbal daun rendah. Kadar timbal pada daun Angsana tidak mencapai $1000 \mathrm{mg} / \mathrm{L}$.
\end{abstract}

Kata kunci: Enzim Peroksidase, Pterocarpus indicus, Klorofil, Timbal (Pb)

\section{Pendahuluan}

Timbal dihasilkan dari proses pembakaran bahan bakar bensin yang mengandung bahan aditif TEL (Tetra Ethyl Lead) yang mempunyai rumus kimia $\left(\mathrm{C}_{2} \mathrm{H}_{5}\right)_{4} \mathrm{~Pb}$ dan TML (Tetra Methyl Lead) dengan rumusnya yaitu $\left(\mathrm{CH}_{3}\right)_{4} \mathrm{~Pb}$ (Palar, 1994). Kendaraan bermotor merupakan sumber pencemaran udara paling dominan di perkotaan, karena sekitar $60-85 \%$ pencemaran udara berasal dari gas buangnya (emisi) dan partikel logam berat seperti timbal (Pb) (Suharsono (1996) dalam
Hidayat (2008). Pencemaran udara akibat paparan timbal berbahaya bagi manusia terutama bagi kesehatan. Timbal dapat merusak jaringan saraf, fungsi ginjal, mempengaruhi organ-organ tubuh antara lain sistem saraf, sistem reproduksi, sistem endokrin dan jantung serta gangguan pada otak (Widowati et. al., 2008).

Penanggulangan timbal di udara dapat menggunakan tanaman sebagai penyerap senyawa logam yang dinamakan fitoremediasi (Firdaus, 2003). Menurut Youngman dalam Yuniarti (2012), 
tanaman yang dapat digunakan sebagai agen fitoremediasi adalah tanaman yang memiliki sifat cepat tumbuh, mengkonsumsi air dalam jumlah yang banyak pada waktu singkat, meremediasi lebih dari satu polutan.

Lokasi pengambilan sampel yaitu jalan H. R. Bunyamin, Ovis Isdiman, Dr. Soeharso dan Gerilya mempunyai kepadatan lalu lintas berbeda, sehingga kadar timbal daun yang berbeda. Di sepanjang jalan tersebut terdapat salah satu tanaman peneduh jalan yaitu Angsana (Pterocarpus indicus). Angsana merupakan salah satu tanaman yang dapat menjadi agen fitoremediasi dan mampu mengakumulasi logam berat seperti timbal (Widowati et.al., 2008). Berdasarkan hasil penelitian Inayah et.al., (2010), secara umum daun Angsana mampu mengakumulasi timbal pada kisaran 1,12 $12,38 \mathrm{mg} / \mathrm{L}$. Kandungan timbal secara normal dalam berbagai jenis tanaman berkisar 0,5 - 3,0 mg/L, atau dengan kata lain kandungan maksimal timbal dalam tanaman adalah 3,0 mg/L (Siregar, 2005).

Tanaman akan merespon masuknya timbal ke dalam jaringan sebagai cekaman lingkungan dan memberikan perubahan sebagai respon adaptasi. Timbal memberikan dampak pada tanaman seperti klorosis, merusak dinding sel, dan menurunkan biosintesis klorofil. Salah satu respon fisiologi dapat dilihat dari kadar klorofil, sedangkan respon enzimatis dilihat dari aktivitas enzim peroksidase (Novita \& Purnomo, 2012).

Toksisitas timbal menyebabkan mekanisme biosintesis klorofil yang berbeda. Pelepasan timbal ke dalam sitoplasma menghambat kerja enzim asam delta aminolevulinat hidratase dan profobilinogenase yang terlibat dalam biosintesis klorofil (Connel \& Miller, 2006).

Enzim peroksidase mempunyai fungsi yang berkaitan dengan proses ketahanan (Yanti, 2011). Enzim antioksidatif tanaman terhadap cekaman lingkungan yakni Superoxide dismutase (SOD), peroksidase (POX) dan Katalase (CAT)
(Erdal \& Demirtas, 2010). Timbal menginduksi peningkatan aktivitas enzim peroksidase dengan cara mengikat gugus fungsi $-\mathrm{SH}$ serta gugus $-\mathrm{COOH}$ sehingga terjadi penghambatan kerja enzim SOD tetapi $\mathrm{H}_{2} \mathrm{O}_{2}$ meningkat (Sharma \& Dubey, 2005). Tanaman yang tahan terhadap cekaman lingkungan terjadi peningkatan aktivitas peroksidase, sedangkan pada tanaman yang peka tidak ada perubahan atau bahkan turun dibandingkan dengan keadaan sehat (Agrios, 2005).

Berdasarkan latar belakang tersebut timbul permasalahan penelitian (1) berapakah kadar timbal yang terakumulasi pada daun Angsana di empat jalan di Purwokerto,(2) apakah ada hubungan paparan timbal dengan kadar klorofil pada daun Angsana di empat jalan di Purwokerto, (3) apakah ada hubungan paparan timbal dengan aktivitas enzim peroksidase pada daun Angsana di empat jalan di Purwokerto.

Tujuan penelitian adalah untuk mengetahui (1) kadar timbal yang terakumulasi pada daun Angsana di empat jalan di Purwokerto, (2) hubungan paparan timbal dengan kadar klorofil pada daun Angsana di empat jalan di Purwokerto, (3) hubungan paparan timbal dengan aktivitas enzim peroksidase pada daun Angsana di empat jalan di Purwokerto.

\section{Metode}

Metode penelitian yang digunakan adalah metode survai dengan teknik purposive sampling. Pengambilan sampel daun diulang masing-masing jalan sebanyak 6 kali. Variabel bebas dalam penelitian berupa kadar timbal pada daun, sedangkan variabel terikat berupa kadar klorofil dan aktivitas enzim peroksidase daun Angsana.

\section{Hasil dan Pembahasan}

\section{Kadar timbal daun dan kepadatan lalu lintas.}

Berdasarkan data distribusi kepadatan lalu lintas (Gambar 1.) menunjukkan adanya variasi jumlah kepadatan lalu lintas baik motor dan mobil pada lokasi yang berbeda. Kepadatan tertinggi yaitu jalan Gerilya dengan jumlah motor dan mobil berturut- 
turut $2857 \pm 393,220$ motor/jam dan $1080 \pm 124,575 \mathrm{mobil} / \mathrm{jam}$ dengan kadar timbal daun sebesar $0.200 \pm 0,016 \mathrm{mg} / \mathrm{L}$. Kepadatan terendah terdapat di. jalan Dr. Soeharso dengan jumlah motor dan mobil masing-masing 1472 $\pm 122,255$ motor/jam dan 379+20,297 mobil/jam dan kadar timbal daun paling rendah yaitu sebesar $0.171 \pm 0,018 \mathrm{mg} / \mathrm{L}$. Jalan H.R Bunyamin memiliki kadar timbal daun tertinggi yaitu $0.252 \pm 0,134 \mathrm{mg} / \mathrm{L}$ dengan jumlah motor dan mobil masing-masing sebesar 2674+781,963 motor/jam dan 588+116,091 $\mathrm{mobi}$ i/jam.

Hubungan kadar timbal daun dan kepadatan lalu lintas disajikan pada Gambar 1.

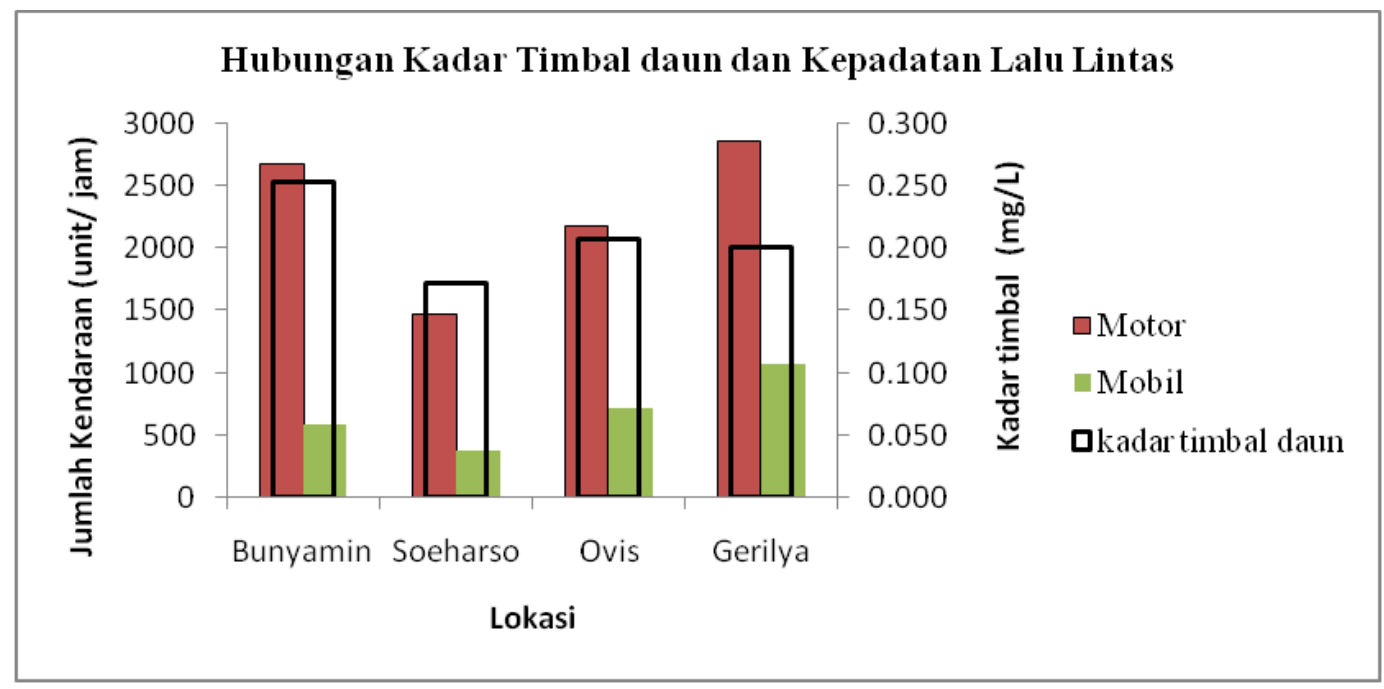

Gambar 1. Diagram Hubungan Kadar Timbal Daun dan Kepadatan Lalu Lintas

Hasil penelitian menunjukkan bahwa kadar timbal daun tertinggi terdapat dijalan H.R. Bunyamin dan terendah berada di jalan Dr. Soeharso.

Tingginya kadar timbal daun pada jalan H.R. Bunyamin dibandingkan dengan Dr. Soeharso disebabkan oleh jumlah kendaraan bermotor yang melintasi pada jalan tersebut. Jumlah kendaraan yang melintasi jalan H.R Bunyamin lebih banyak dibandingkan dengan Dr. Soeharso. Lalu lintas kendaraan bermotor yang padat menyebabkan kadar polutan timbal $(\mathrm{Pb})$ yang di emisikan ke lingkungan sekitar meningkat (Antari \& Sundra, 2002), hal tersebut mempengaruhi penyerapan timbal oleh daun (Sulasmini et.al., 2007).

Partikel timbal dari udara akan menempel di permukaan daun dan dapat masuk ke dalam jaringan. Mekanisme masuknya partikel timbal yaitu melalui penyerapan pasif melewati celah stomata dan terakumulasi di dalam jaringan (Agustina, 2008). Menurut Rangkuti (2003), diameter rata-rata partikel timbal adalah 2 $\mu \mathrm{m}$, lebih kecil dari ukuran celah stomata yang berkisar $10 \mu \mathrm{m}$ dengan lebar 2-7 $\mu \mathrm{m}$, sehingga menyebabkan prtikel tersebut mudah masuk melewati stomata.

Kepadatan lalu lintas tertinggi terdapat di jalan Gerilya dengan tingkat kadar timbal daun terendah kedua dari semua lokasi penelitian. Rendahnya kadar timbal daun disebabkan, lokasi tersebut terdapat beberapa tanaman peneduh jalan selain Angsana. Banyaknya tanaman peneduh serta jenis tanaman di sekililing lokasi merupakan faktor yang mempengaruhi kadar timbal $(\mathrm{Pb})$ pada tanaman (Siregar, 2005).

\section{Kadar Timbal Daun Angsana dan Kadar Klorofil}

Hasil pengukuran kadar timbal daun dan kadar klorofil di empat lokasi disajikan dalam Gambar 2. 


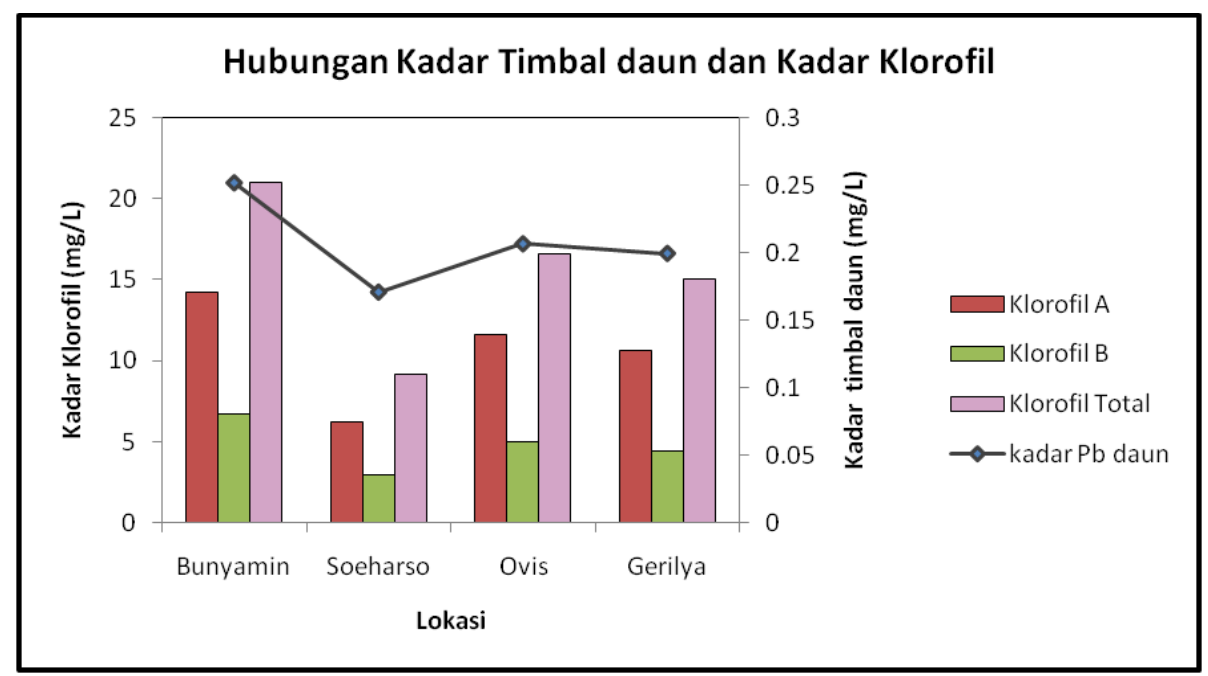

Gambar 2. Diagram Hubungan Kadar Timbal Daun dan Kadar Klorofil

Kadar klorofil daun berkisar antara 9,0$21,0 \mathrm{mg} / \mathrm{L}$. Kadar klorofil tertinggi baik klorofil A, B serta total terdapat di jalan H.R Bunyamin sebesar $14,233 \pm 2,265 \mathrm{mg} / \mathrm{L}$, $6,736 \pm 1,355 \mathrm{mg} / \mathrm{L}$ dan $20,963 \pm 3,955 \mathrm{mg} / \mathrm{L}$ dengan kadar timbal daun tertinggi yaitu sebesar $0,252 \pm 0,135 \mathrm{mg} / \mathrm{L}$. Jalan $\mathrm{Dr}$. Soeharso memiliki kadar klorofil A, B dan total terendah yaitu sebesar $6,220 \pm 2,166$ $\mathrm{mg} / \mathrm{L}, 2,992 \pm 1,003 \mathrm{mg} / \mathrm{L}$ dan $9,140 \pm 3,166$ $\mathrm{mg} / \mathrm{L}$ dengan kadar timbal daun terendah sebesar 0,171+0,018 mg/L.

Hasil uji regresi linear nilai $r$ hitung $<r$ tabel pada klorofil A, B dan total secara berturut-turut adalah 0,066 < 0,343; 0,093 < 0,343 ; dan $0,075<0,343$. Hal tersebut menunjukkan bahwa tidak ada hubungan antara kadar timbal daun dan kadar klorofil A, B dan total.

Penghambatan biosintesis klorofil terjadi karena timbal dapat mengurangi asupan $\mathrm{Mg}$ dan Fe sehingga menyebabkan perubahan pada struktur dan jumlah klorofil (Novita \& Purnomo, 2012). Timbal didalam sitoplasma akan menghambat aktivitas Asam Delta Amino Levulenat Dehidratase (ALAD) dan profobilinogenase yang terlibat dalam biosintesis klorofil (Sembiring dan Sulityawati, 2006). $\mathrm{Pb}^{2+}$ akan menghambat aktivitas ALAD dengan cara berikatan dengan gugus $\mathrm{SH}$ - (Saygideger et. al., 2004).

Hasil penelitian menunjukkan kadar klorofil tertinggi baik klorofil A, B dan total terdapat di jalan H. R. Bunyamin dengan kadar timbal daun tertinggi. Jalan Dr.Soeharso memiliki kadar klorofil A, B dan total terendah dengan kadar timbal daun terendah. Hal tersebut menunjukkan tidak adanya proses penghambatan biosintesis klorofil pada daun Angsana oleh timbal. Biosintesis klorofil tidak terhambat disebabkan oleh kadar timbal daun yang masih dalam batas toleransi tanaman Angsana, sehingga kadar klorofil daun Angsana tidak mengalami perubahan. Kadar timbal daun di empat lokasi berkisar 0,1 - 0,25 mg/L. Batas toksisitas logam berat timbal pada daun tanaman tingkat tinggi adalah 1000 ppm (mg/L) (Connel \& Miller, 2006). Kadar normal timbal daun dalam pohon $\leq 10 \mathrm{ppm}(\mathrm{mg} / \mathrm{L})$ (Alloway \& Ayers, 1993). Kandungan timbal pada daun Angsana belum melampaui batas toksisitas terhadap tanaman.

Hasil uji anova menunjukkan bahwa tidak ada hubungan antara kadar timbal daun dan kadar klorofil A, B dan total. Kadar timbal daun masih di dalam kisaran toleransi pada daun Angsana, sehingga kadar klorofil tidak mengalami perubahan. Saygideger et.al., (2004), menyatakan bahwa kelebihan timbal dalam tanaman dapat mengganggu dan menghambat berbagai proses fisiologis salah satunya adalah penghambatan biosintesis klorofil. Menurut Sharma dan Dubey (2005), keracunan timbal akan menghambat pertumbuhan tanaman karena mengalami klorosis.

\section{Kadar Timbal Daun Angsana dan Aktivitas Enzim Peroksidase}

Hasil pengukuran kadar timbal daun Angsana dan aktivitas enzim peroksidase disajikan pada Gambar 3 


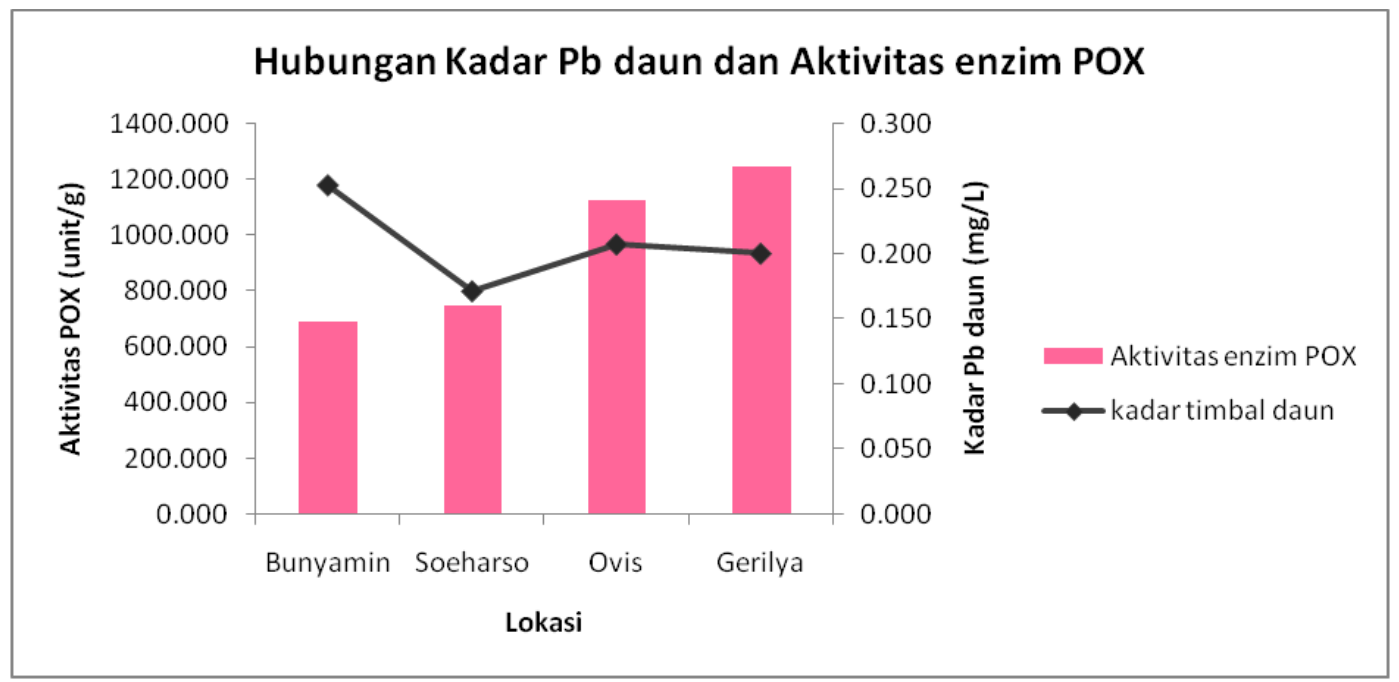

Gambar 3. Diagram Hubungan Kadar Pb Daun dan Aktivitas Enzim Peroksidase

Berdasarkan data pada Gambar 3. aktivitas enzim peroksidase tertinggi terdapat pada jalan Gerilya yaitu $1246 \pm 114,981$ unit/g dengan kadar timbal daun sebesar 0,200 $\pm 0,016 \mathrm{mg} / \mathrm{L}$. Aktivitas enzim peroksidase terendah terdapat pada jalan H.R Bunyamin sebesar 693,33_ + 314,453 unit/g dengan kadar timbal daun
$0,252 \pm 0,134 \mathrm{mg} / \mathrm{L}$.

Hasil uji regresi linear menunjukkan bahwa nilai rhitung memiliki korelasi negatif yaitu $-0,409$ dengan $r$ hitung $>r$ tabel yaitu sebesar $0,409<0,343$. Hal tersebut menunjukkan bahwa ada hubungan aktivitas enzim peroksidase dengan kadar timbal daun.

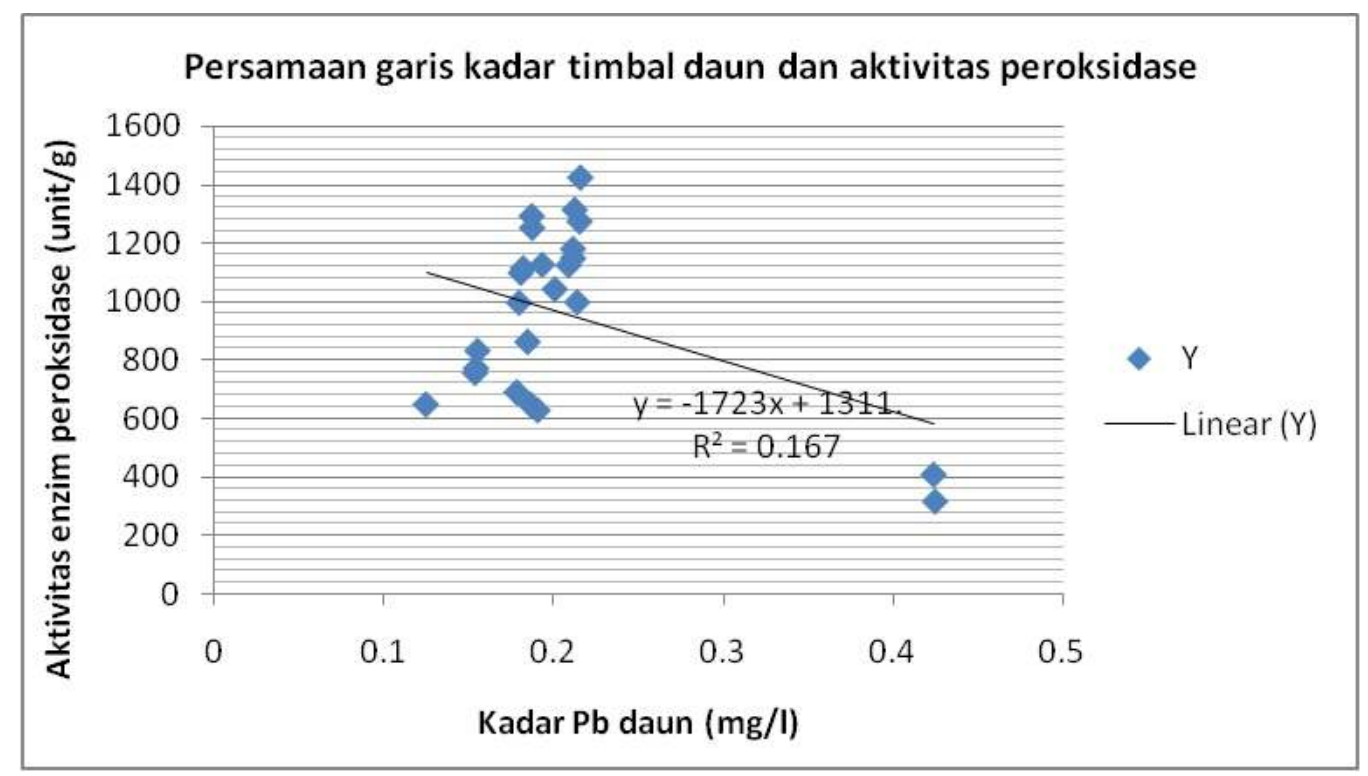

Gambar4. Persamaan Garis Hubungan Kadar Timbal Daun dan Aktivitas Enzim Peroksidase

Berdasarkan Gambar 4 hubungan antara aktivitas enzim peroksidase dan kadar timbal daun memiliki nilai $\mathrm{R}^{2}$ yaitu 0,167 . Hal tersebut menunjukkan bahwa ada hubungan dari aktivitas enzim peroksidase dengan kadar timbal daun dengan derajat keeratan yang rendah yaitu sebesar $16,7 \%$. 
Tabel 1. Anova Regresi Aktivitas Enzim Peroksidase dan Kadar Timbal Daun

\begin{tabular}{|l|r|r|r|r|r|r|}
\hline \multirow{2}{*}{$\begin{array}{c}\text { Sumber } \\
\text { keragaman }\end{array}$} & df & \multirow{2}{*}{ JK } & \multirow{2}{*}{ KT } & \multirow{2}{*}{$F_{\text {hit }}$} & \multicolumn{2}{c|}{$F_{\text {tabel }}$} \\
\cline { 6 - 8 } & & & & 0,05 & 0,01 \\
\hline Regresi & 1 & 339698,74 & 339698,74 & 4,435 & 4,30 & 7,94 \\
\hline Error & 22 & 1685217,10 & 76600,78 & & & \\
\hline Total & 23 & 2024915,83 & & & & \\
\hline
\end{tabular}

Aktivitas enzim peroksidase mengalami perubahan dengan terakumulasinya timbal dalam daun Angsana. Tanaman memiliki mekanisme tersendiri untuk bertahan dari kerusakan yang disebabkan oleh logam berat (Erdal \& Demirtas, 2010). Jalan Dr. Soeharso memiliki kadar timbal daun terendah dan menunjukkan aktivitas enzim peroksidase terendah kedua. Aktivitas enzim peroksidase tertinggi ditunjukkan pada jalan Gerilya dengan kadar timbal daun tertinggi ketiga dari keempat lokasi. Jalan H.R. Bunyamin memiliki aktivitas enzim peroksidase terendah dengan kadar timbal daun tertinggi. Hal tersebut diduga pada jalan H.R. Bunyamin tingkat toleransi tanaman Angsana lebih baik dari ketiga lokasi yang lain. Erdal dan Demirtas (2010) menyatakan bahwa tanaman akan meningkatkan aktivitas enzim antioksidan pada saat tingkat cekaman logam berat sudah melampaui batas toleransi tanaman.

Hasil uji regresi menunjukkan kadar timbal daun memiliki hubungan dengan aktivitas enzim peroksidase dengan pengaruh yang rendah. Rendahnya pengaruh tersebut disebabkan kadar timbal daun pada keempat lokasi belum melampaui batas toksisitas daun Angsana. Connel \& Miller (2006), menyatakan bahwa batas toksisitas logam berat timbal pada daun tanaman tingkat tinggi adalah 1000 ppm (mg/L). MenurutAlloway \& Ayers (1993),

kadar normal timbal daun dalam pohon $\leq 10 \mathrm{ppm}$ dan nilai toksisitas tanaman akibat timbal adalah 30-300 ppm (mg/L). Kadar timbal daun masih di dalam kadar normal sehingga kurang berpengaruh terhadap aktivitas enzim peroksidase.

Kadar timbal yang masuk ke dalam jaringan akan di respon sebagai cekaman lingkungan, sehingga tanaman Angsana mengalami perubahan enzimatis sebagai respon adaptasi. Connel dan Miller (2006) menyatakan mekanisme pertahanan tanaman terhadap toksisitas logam berat adalah membentuk enzim dengan gugus fungsi sulfihidril ( $\mathrm{SH}-$ ) dan karboksilat $(\mathrm{COOH}-)$ yang bereaksi dengan timbal dengan cara yang berbeda. Menurut Sharma \& Dubey (2005), timbal berikatan dengan gugus fungsi sulfihidril serta karboksilat yang menghambat kerja enzim Superoxide dismutase kemudian meningkatkan aktivitas enzim peroksidase. Peningkatan aktivitas enzim peroksidase tersebut menunjukkan tingkat ketahanan tanaman, semakin tinggi kadar timbal yang masuk ke dalam jaringan menyebabkan tingginya aktivitas enzim peroksidase tanaman tersebut. Agrios (2005), mengemukakan bahwa tanaman yang tahan terhadap cekaman lingkungan mengalami peningkatan pada aktivitas enzim peroksidase, sedangkan tanaman yang peka tidak mengalami perubahan atau bahkan mengalami penurunan dalam pertumbuhan tanaman tersebut.

\section{Simpulan}

Berdasarkan hasil penelitian tersebut disimpulkan bahwa kadar timbal daun pada empat jalan di Purwokerto berkisar 0,1-0,25 mg/L. Tidak ada hubungan antara paparan timbal dengan kadar klorofil, dan terdapat hubungan antara paparan timbal dengan aktivitas enzim peroksidase.

\section{Daftar Referensi}

Agrios, G.N., 2005. Plant Pathology. 5th ed. San Diego: Academic Press

Agustina, E., 2008. Kandungan Timbal (Pb) dan Pengaruhnya dalam Jaringan Daun Angsana (Pterocarpus indicus) Di Kampus I Universitas Islam Negeri 
(UIN) Syarif Hidayatullah. Skripsi. Jakarta : Universitas Islam Negeri (UIN) Syarif Hidayatullah.

Alloway, B.J. \& Ayres, D.C., 1993. Chemical Principles of Environmental Pollution. London : Blackic Academic and Professional.

Antari, A.A.R.J. \& Sundra,I. K., 2002. Kandungan $\mathrm{Pb}$ pada Tanaman Peneduh Jalan Di Kota Denpasar: Jurnal. Universitas dayana. Denpasar. http://ejournal.unud.ac.id/. 16 November 2013.

Arnon, D.I.,1949. Copper Enzyme in Isolated Chloroplasts Polyphenoloxidase in Beta vulgaris. Plant Physiology, 24 (1), pp. 1-15.

Connel, D.W. \& Miller, G.J., 2006. Kimia dan Ekotoksikologi Pencemaran. Jakarta: UI Press, diterjemahkan Yanti Koestoer.

Erdal, S. \& Demirtas, A., 2010. Effect of Cement Flue Dust A Cement Factory On Stress Parameters And Diversity Of Aquatic Plants. Toxicology and Industrial Health, 26, pp. 339-343.

Fergusson, J.E., 1990. The Heavy Element Chemistry, Environmental Impact And Health Effect. Oxford : Fergusson Press.

Firdaus, L. N., 2003. Teknologi Fitoremediasi Lingkungan. http://www.terranet.or.id/ goto berita.php?id=14350.html (diakses tanggal 01 Oktober 2013).

Herlich, K., 1991. Official Methods of Analisis. AOAC.Virginia. USA.

Hidayat, I. W., 2008. Evaluasi Jalur Hijau Jalan sebagai Penyangga Lingkungan Sekitarnya dan Keselamatan Pengguna Jalan Bebas Hambatan Jagorawi. Tesis. Bogor : Sekolah Pascasarjana Institut Pertanian Bogor.

Inayah, S. N., Las, T. \& Yunita, E., 2010. Kadar $\mathrm{Pb}$ pada Daun Angsana (Pterocarpus indicus) dan Rumput Gajah Mini (Axonopus. sp) di Jalan Protokol Kota Tangerang. Valensi, 2 (1), pp. 340-346.

Janda, T., Szalai, G., Rios-Gonzales, K., Veisa, O., \& Paldi, E., 2003. Comparative Study of Frost Tolerance and Antioxidant Activity In Cereals. Plant Science, 164, pp. 301-306.

Novita, Y \& Purnomo, T., 2012. Penyerapan Logam Timbal $(\mathrm{Pb})$ dan Kadar Klorofil Elodea Canadensis pada Limbah Cair Pabrik Pulp dan Kertas. LenteraBio, 1 (1), pp. 1-8.

Palar, H., 1994. Pencemaran dan Toksikologi Logam Berat. Jakarta : Rineka Cipta.

Rangkuti,M.N., 2003.Kemampuan Menyerap Timbal $(\mathrm{Pb})$ pada daun Beberapa Jenis Tanaman Penghijauan Jalan Tol Jagorawi: Analisis Struktur Anatomi dan Histokimia. Tesis. Bogor: Sekolah Pascasarjana IPB.

Saygideger, S., Dogan, M. \& Keser, G., 2004. Effect of Lead and $\mathrm{pH}$ on Lead Uptake, Chlorophyll and Nitrogen Content of Typha latifolia L. and Ceratophyllum domersum L. International Journal Of Agriculture and Biology, 6 (1), pp. 168-172.

Sembiring, E. \& Sulistyawati, E., 2006. Akumulasi $\mathrm{Pb}$ dan Pengaruhnya pada Kondisi Daun Swietenia macrophylla King. Prosiding Seminar Nasional Penelitian Lingkungan, Kampus Institut Teknologi Bandung, 17-18 Juli 2006. Bandung.

Sharma, P \& Dubey, S., 2005. Lead Toxicity in Plants. Braz. J. Plant Physiol, 17 (1), pp. 35-52.

Siregar, E. B. M., 2005. Pencemaran Udara Respon Tanaman dan Pengaruhnya pada Manusia, Karya IImiah, Universitas Sumatera Utara: Medan. Dipublikasikan e-USU Repository, (diakses 16 November 2013).

Sulasmini, L.K. M., Mahendra, M.S. \& Lila, K.A., 2007. Peranan Tanaman Penghijauan Angsana, Bungur dan Daun Kupu-Kupu Sebagai Penyerap Emisi $\mathrm{Pb}$ dan Debu Kendaraan Bermotor Di Jalan Cokroaminoto, Melati dan Cut Nyak Dien Di Kota Denpasar. Ecotrophic, 2 (1), pp. 19075626.

Widowati, W., Sastiono, A., \& Jusuf,R., 2008. Efek Toksik Logam. Yogyakarta: Andi. 
Yanti, Y. 2011., Aktivitas Peroksidase Mutan Pisang Kepok dengan Ethyl Methane Sulphonate (EMS) secara In Vitro. Jurnal Natur Indonesia, 14 (1), pp. 3236.
Yuniarti, S. I., 2012. Seleksi Tanaman Remediator Logam Kromium Di Daerah Industri Sukaregang Garut. Skripsi. Bandung : Universitas Pendidikan Indonesia. 